\title{
EGY URALKODÓI MELLÉKREZIDENCIA ÉPÍTÉSZETI ELEMEI A TATAI VÁR 15. SZÁZADI KŐFARAGVÁNYAI
}

\section{GILLICH OLIVÉR ${ }^{1}$}

Magyar Régészet 10. évf. (2021), 2. szám, pp. 38-46. https://doi.org/10.36245/mr.2021.2.1

A Komárom-Esztergom megyében fekvö tatai vár, mint kiemelt fontosságú müemlék, valamint kedvelt kirándulóhely és turisztikai látványosság sokak számára jól ismert helyszín. A festöi szépségü Öreg-tó partján emelkedö középkori várépítmény a maga nemében rendkívüli látványt nyújt az arra járóknak. Annak ellenére, hogy a vár a késö középkorban fontos reprezentativ funkcióval rendelkezett, régészeti feltárása pedig már fél évszázaddal ezelött megtörtént, a szakma mindeddig viszonylag keveset foglalkozott a vár épitéstörténetének és reprezentációs szerepének részletesebb kutatásával. Az épitmény jelen állapotában ugyan keveset mutat az eredeti, 15. századi kinézetéböl, azonban a megmaradt álló falak és a köfaragványok egy csoportjának alapos vizsgálata közelebb vihetnek minket a pontosabb megismeréshez.

Kulcsszavak: Tata, vár, 15. század, uralkodói reprezentáció, kőfaragvány, ablakkeret, mellvéd

\section{A TATAI VÁR TÖRTÉNETE}

Jelen ismereteink szerint a 15. század első évtizedében, Luxemburgi Zsigmond király (1387-1437) uralkodása alatt került sor a tatai vár felépítésére (B. SzATMÁRI 1975, 276). A szabályos, közel négyzetes alaprajzú, négy saroktoronnyal rendelkező várépület (1. kép) az érett gótika stílusjegyeit viselte magán (B. SzATMÁRI 1974, 47), és uralkodói mellékrezidenciaként használták. Zsigmond király egyik kedvelt tartózko-

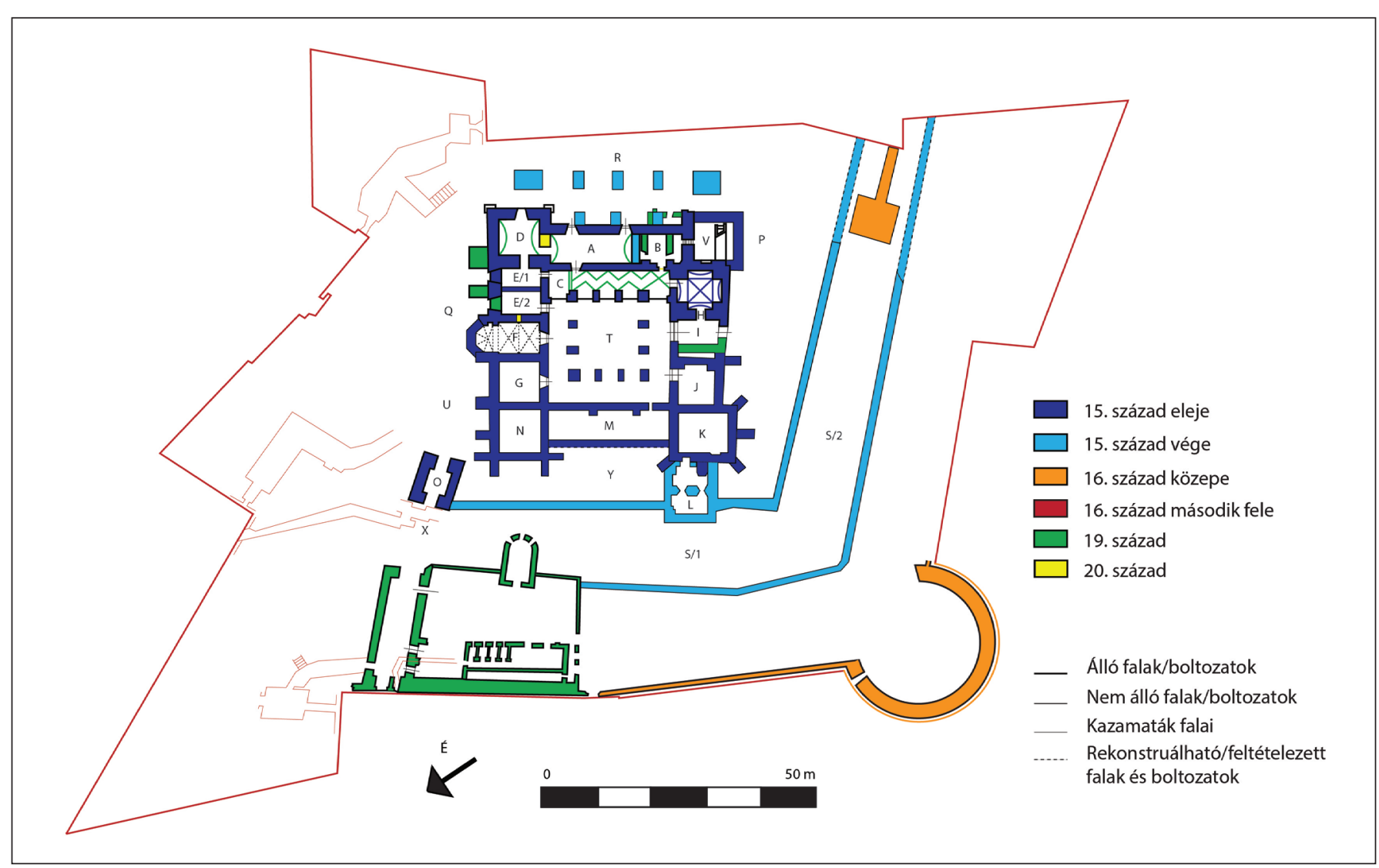

1. kép. A tatai vár alaprajza (B. SzATMÁRI 1974 nyomán)

1 E-mail: gillich.oliver@gmail.com 
Gillich Olivér • Egy uralkodói mellékrezidencia épitészeti elemei. A tatai vár 15. századi köfaragványai

dási helyévé vált és évente több alkalommal is megfordult itt hosszabb-rövidebb időszakokra az uralkodó ismert tartózkodási helyeit felsoroló itinerárium szerint (ENGEL \& C. Tо́тн 2005, 89-130). Ennek ellenére Zsigmond közel másfél-két évtized után, valamikor az 1420-as években a várat elzálogosította id. Rozgonyi István temesi ispánnak (ENGEL 1977, 161), majd ezt követően körülbelül fél évszázadon keresztül a Rozgonyi-család kezében maradt (SchmidtMAYer 2012, 123-140). Pontosan nem ismert időpontban, de írott források alapján feltehetően az 1470-es évek elején Hunyadi Mátyás király (1458-1490) birtokába került, amely így ismételten uralkodói mellékrezidenciaként funkcionálhatott. Mátyás azonban kevesebb alkalommal látogatta meg Tatát, amiről az itineráriuma is tanúskodik (HoRvÁTH 2011, 62-131). Halála után egy rövid időszakra törvénytelen fiáé, Corvin Jánosé lett, majd 1492-1493 táján újra uralkodói kézbe, II. (Jagelló) Ulászlóhoz (1490-1516) került (NeumanN 2010, 76). Az ő idején ismét előtérbe került a vár szerepe, különösen kiemelkedö az 1510-es év, amikor országgyülést tartottak a falai között (C. Tо́тн 2010, 16). Mátyás király uralkodásának második felére és II. Ulászló regnálásának első felére keltezhető a vár második építési periódusa, amely azonban lényegesen nem változtatott az alaprajzon, csupán kiegészítette azt (1. kép). Ekkor épült fel az északnyugati saroktorony elé egy négyszögletes alaprajzú építmény (L betűvel jelölve; 1. kép), a vizesárkot kívülről és belülről övező kerítőfalak (utóbbi belekötött az említett négyszögletes építménybe), valamint a vár tóparti homlokzata elött nyolc pilléren nyugvó ( $\mathrm{R}$ betủvel jelölve; 1. kép), függőkertként azonosított építmény (B. SzATMÁRI 1974, 47, 52).

A mohácsi csatát (1526) követő viszontagságos időszakban a tatai vár számára nehéz évtizedek következtek. Ekkorra végleg elvesztette uralkodói mellékrezidencia szerepét és betagozták a létrejövő végvári rendszerbe. A 16. század második felében az ostromok és az átépítések miatt súlyos károk érték a középkori várat (SchÖNERNÉ 1968; Tо́Tн 1998), ahogyan az Georg Hoefnagel 1600-ban készült metszetén is látható (2. kép). Az épületet a 18. században az Esterházy-család szerezte meg, akik elbonttatták a vár északi, keleti és nyugati szárnyát, a törmelékeikkel pedig a belső vizesárkot feltöltötték. Csak a déli palotaszárnyat hagyták meg (3-5. kép) (B. SzATMÁRI 1974, 48), amit a 19. században két ütemben átépítettek (ERDEI 1971, 80).

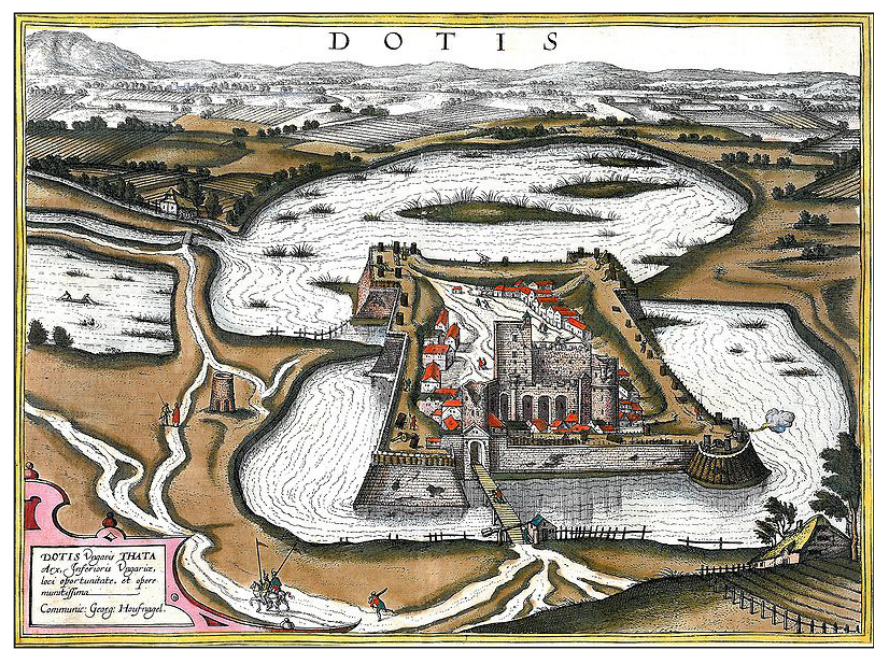

2. kép. Georg Hoefnagel 1600-ban készitett metszete a tatai várról (forrás: keptar.niif.hu)

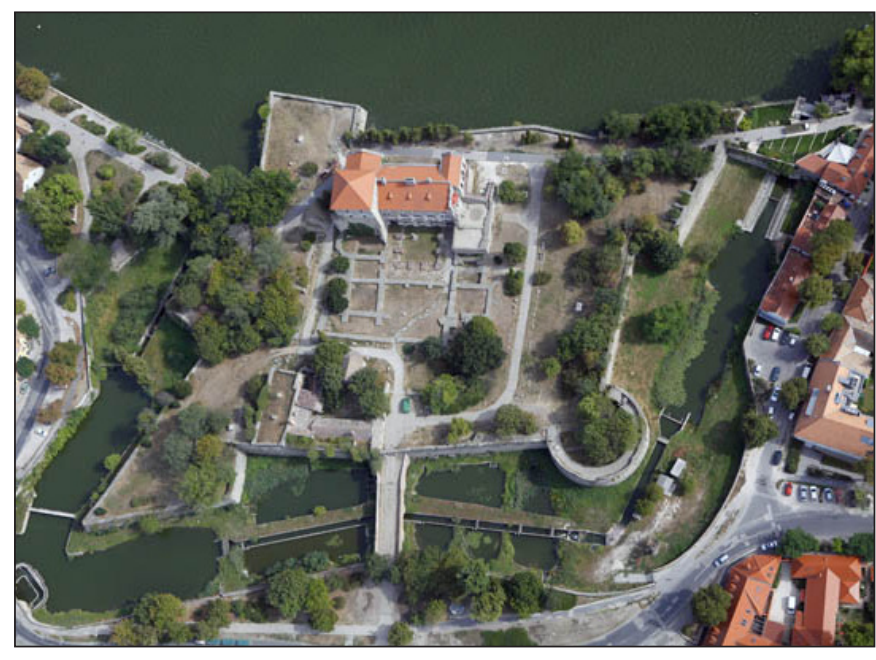

3. kép. A vár madártávlatból (forrás: legifelvetel.hu)

\section{KUTATÁSTÖRTÉNET}

Az építmény elpusztult részeinek régészeti feltárására 1965-1972 között került sor (B. SzATMÁRI, 1974, 45-53). Ennek során tisztázni sikerült a vár pontos alaprajzát, azonban az is nyilvánvalóvá vált, hogy a korábban említett, a 18. század közepén elvégzett tereprendezéssel a keleti, északi és nyugati palotaszárnyak falait a legtöbb helyen szinte teljes mértékben visszabontották a sziklafelszínig (B. SzATMÁRI, 1974, 46). Amíg itt egyértelmüen szintsüllyesztést hajtottak végre, addig a déli palotaszárny és az Öreg-tó közötti területet (R betűvel jelölve; 1. kép) a 19. században feltöltötték, így annak járószintje több méterrel maga- 
Gillich Olivér • Egy uralkodói mellékrezidencia épitészeti elemei. A tatai vár 15. századi köfaragványai

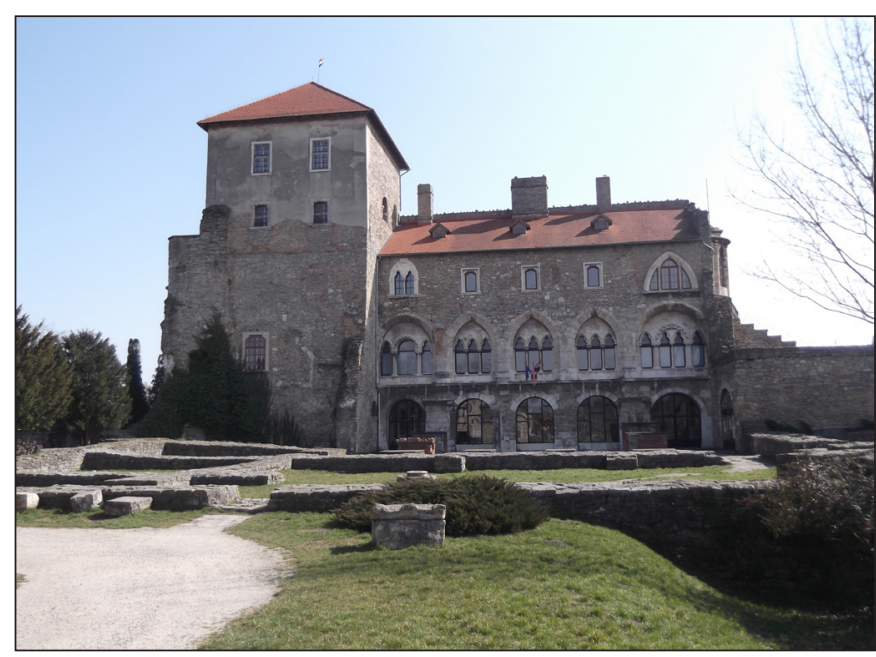

4. kép. A tatai vár egykori déli szárnyának északi (belsö) homlokzata (a szerzö felvétele)

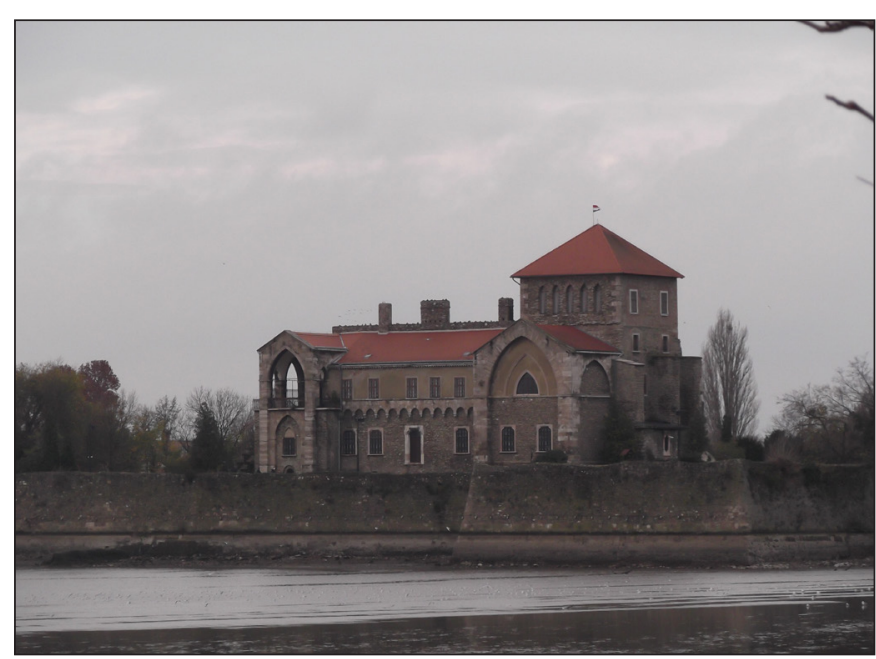

5. kép. A vár látképe a tó felöl (a szerzö felvétele)

sabbra került (Ásatási jelentés, 1969). Leleteket - köztük kőfaragványokat - csak az északi szárny pincéjében ( $\mathrm{M}$ betűvel jelölve; 1. kép), a belső vizesárok feltárt északnyugati szakaszában ( $\mathrm{S}$ betüvel jelölve; 1. kép) és más, a tereprendezés által nem érintett területeken (P, Q és U betükkel jelölve; 1. kép) találtak nagyobb számban (Ásatási jelentések, 1965-1972). Az ásatás mellett a déli palotaszárny felújítását is elvégezték. A vakolatok eltávolítása után több, eredeti helyén található és befalazott középkori ablak és ajtó került napvilágra, melyek egy részét kibontották és helyreállították (Ásatási jelentés, 1969-1971). A várral kapcsolatos egyik legfontosabb épületrégészeti megfigyelést is ekkor tették: a ma álló tornyot (E betűvel jelölve; 1. kép) a 19. században emelték, azonban az északi fala nagyrészt középkori eredetü, ami ráadásul egykor egy kétszintes várkápolna déli fala volt (4. kép). Különösen szerencsésnek mondható ez a helyzet, ugyanis a falról leolvasható az egykori szakrális tér szerkezete, ami egyben a vár legmagasabban álló eredeti falazata is (BuZÁs 2010, 94).

\section{A KÖZÉPKORI KŐFARAGVÁNYOK ÉS REKONSTRUKCIÓS LEHETŐSÉGEIK}

A középkori tatai vár építészeti reprezentációjáról csak a déli palotaszárny egyes elemeinek, illetve a régészeti feltárás során napvilágra került kőfaragvány-töredékeknek a vizsgálatával kaphatunk képet. A déli szárnyban ma is megfigyelhetünk több eredeti helyén található, helyreállított vagy részlegesen megmaradt középkori ajtó- illetve ablakkeretet, amelyek többsége besorolható a fentebb említett két, 15. századi építési periódusba. A keltezésükben a Medium Regni más uralkodói rezidenciaépítkezéseinek (elsősorban a budai és a visegrádi várak) mürészleteivel való párhuzam segített. Ugyanezek mondhatók el az egyes terek lefedését szolgáló boltozatokkal kapcsolatban is.

A 20. század 60-as, 70-es éveiben folytatott ásatások során felszínre hozott kőfaragvány töredékek száma meghaladja a 200-at. Nagyobb számban érett és késő gótikus elemek találhatók a leletanyagban, mellettük mindössze alig két tucat példányban képviseltetik magukat a kora reneszánsz töredékek. A legtöbb faragvány a gótikus ajtó- és ablakkeret, illetve a boltozati elemek csoportjába sorolhatók. Kisebb, de jelentős egységeket alkotnak még a mellvéd-töredékek, a konzolok, valamint a különböző építészeti fejezetek és lábazatok. Az említett töredékek alapján több elméleti rekonstrukciót is sikerült megrajzolnom: a vár keleti főkapuját, a kápolna nyugati kapuját, két gótikus osztott ablakkeretet, egy késő gótikus $2 \times 2$ osztatú ablakot, valamint két mellvédet. Ezek közül a továbbiakban a csupán a legreprezentatívabbakat (fökapu, 2×2-es ablak, mellvédek) kívánom bemutatni, melyek mind a tatai vár egykori megjelenésének egy-egy apró díszes részletét hivatottak megjeleníteni. Meg kell még említeni a reneszánsz ballusztrádos korlátot is, melynek korábban nem csak elméleti rekonstrukciója készült el, hanem az eredeti töredékek felhasználásával sikerült újraalkotni a szerkezetet (BuZÁs 2008; BuZÁs 2010, 107-108). 
Gillich Olivér • Egy uralkodói mellékrezidencia épitészeti elemei. A tatai vár 15. századi köfaragványai

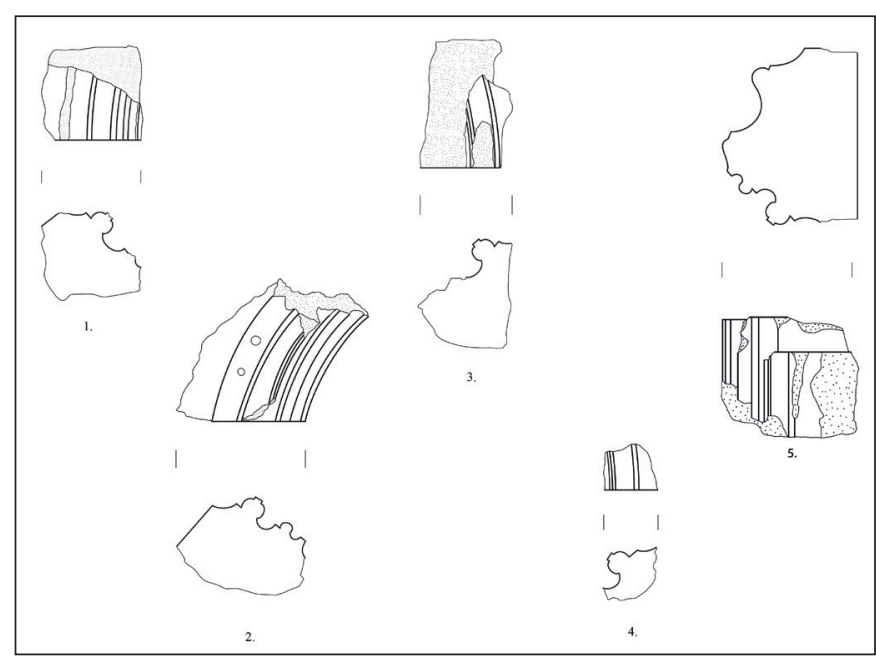

6. kép. A fökapu faragványai

Az 1968. évi ásatáson a vár keleti homlokzata elött, annak is a déli részén ( $\mathrm{Q}$ betüvel jelölve; 1 . kép) több nagyméretü, gazdagon tagolt profillal ellátott kőfaragvány (6. kép) került elő (Ásatási jelentés, 1968). A töredékekről a profiljaik alapján egyértelmüen megállapítható volt, hogy valamikor (egy kivétellel!) ugyanazon nyíláskeret részét képezték (7. kép), ami nem más volt, mint a vár egykori főkapuja. Ezt az elméletet támasztja alá Giulio Turco 1569-ben készült váralaprajza (8. kép) (SCHÖNERNÉ 1968, 263), melyen a várkápolnától délre jelöl bejáratot, vagyis ugyanott, ahonnan az említett faragott kövek is elökerültek. Továbbá szerencsés körülménynek tekinthető az is, hogy a fentebb említett, 18. század közepi tereprendezés a várnak ezt a kis területét nem érintette. Ennek köszönhetően kerülhetett elő ez a néhány kőfaragvány a fókapu eredeti elhelyezkedésének közvetlen közelében. Az egykori nyílást ismeretlen időpontban megszüntették és befalazták, így ma már semmilyen nyoma sem fedezhetö fel a külső falszöveten (9. kép). Jelenleg a leletanyagban öt darab faragvány található, ami ehhez a szerkezethez sorolható: ebből négy íves, egy pedig egyenes szakaszhoz tartozó rétegkő. Ezek alapján a főkapu elméleti rekonstrukciói elkészíthetők voltak. Rögtön két változatot készítettem el, ugyanis annak ellenére, hogy első ránézésre félköríves lezáródású megoldás képzelhető el (10. kép), véleményem szerint a csúcsíves kialakítás sem zárható ki (11. kép). A fökapu eredeti méreteit azonban nem lehet ezek alapján meghatározni, csupán egyetlen adatra lehet következtetni: a félköríves lezáródás esetén a fökapu szélessége a töredékek hajlásszöge alapján megközelítőleg 1,6-1,8 m lehetett. A

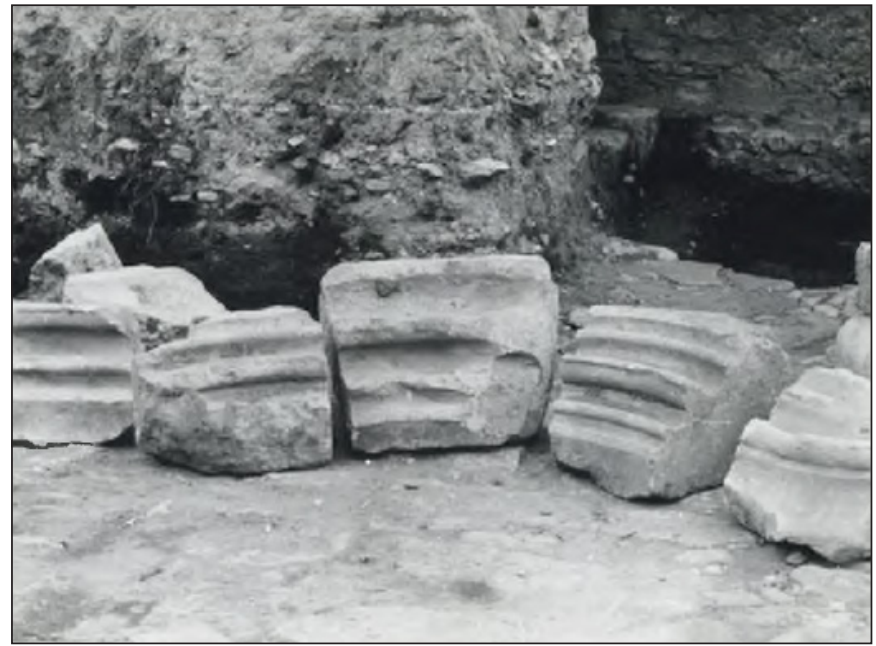

7. kép. A fökapu faragványai az 1968-as elökerülésük után

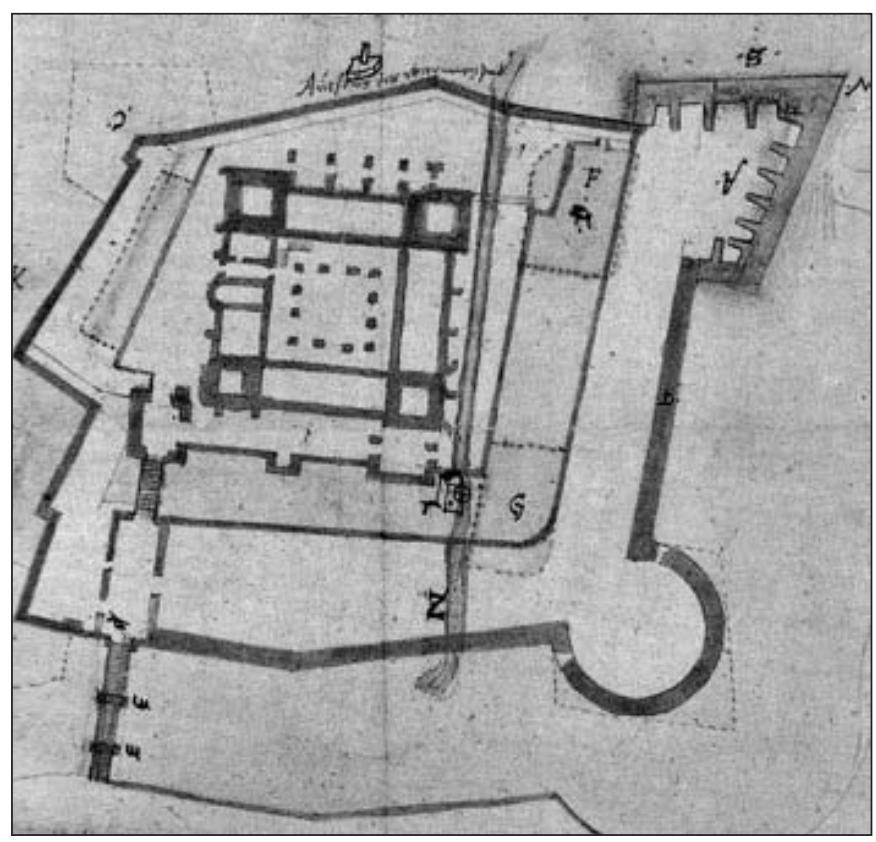

8.kép. Giulio Turco 1569-es felmérése (SCHÖNERNÉ 1968, 263)

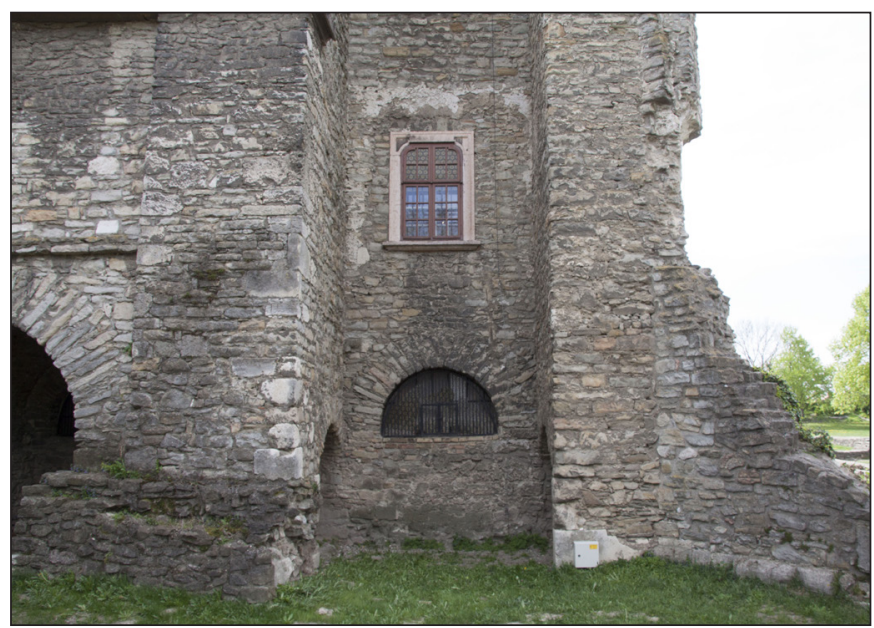

9. kép. A fókapu egykori feltételezett helye 


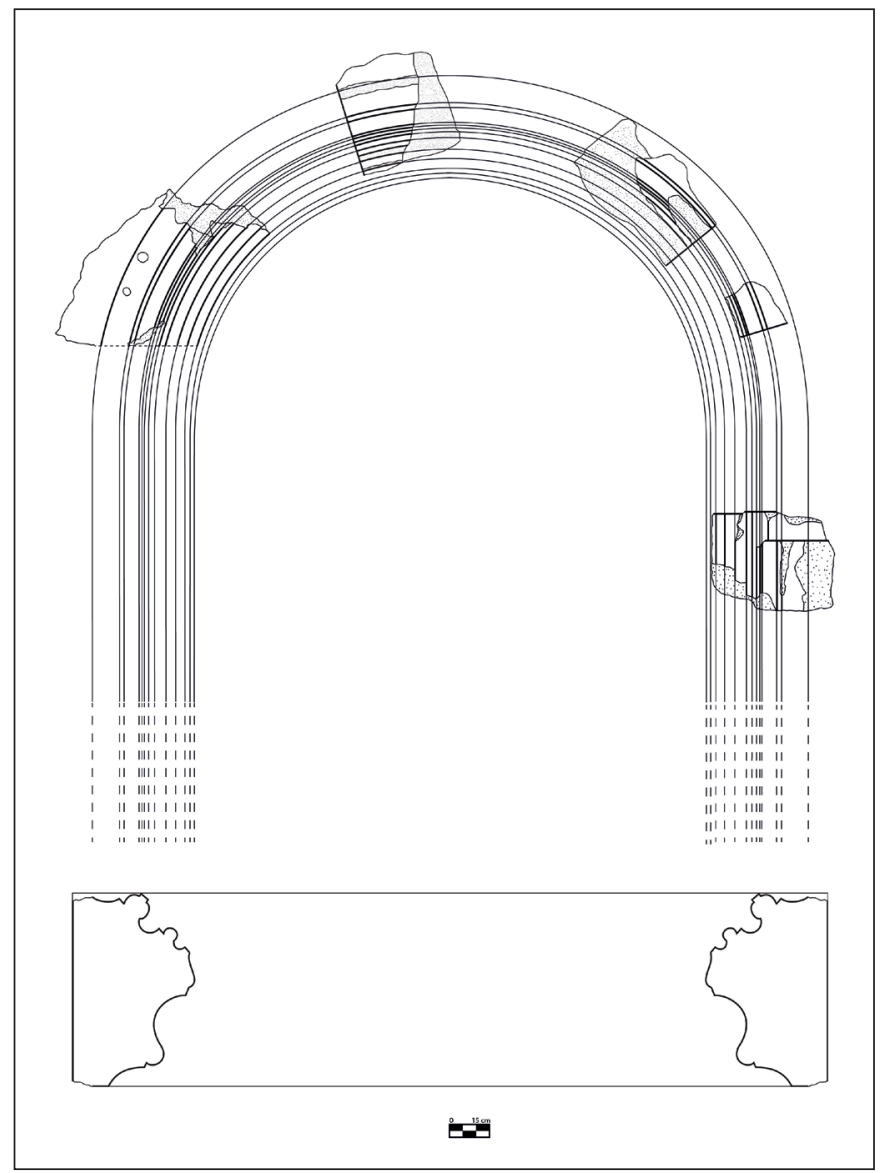

10. kép. A fökapu elméleti rekonstrukciója I.

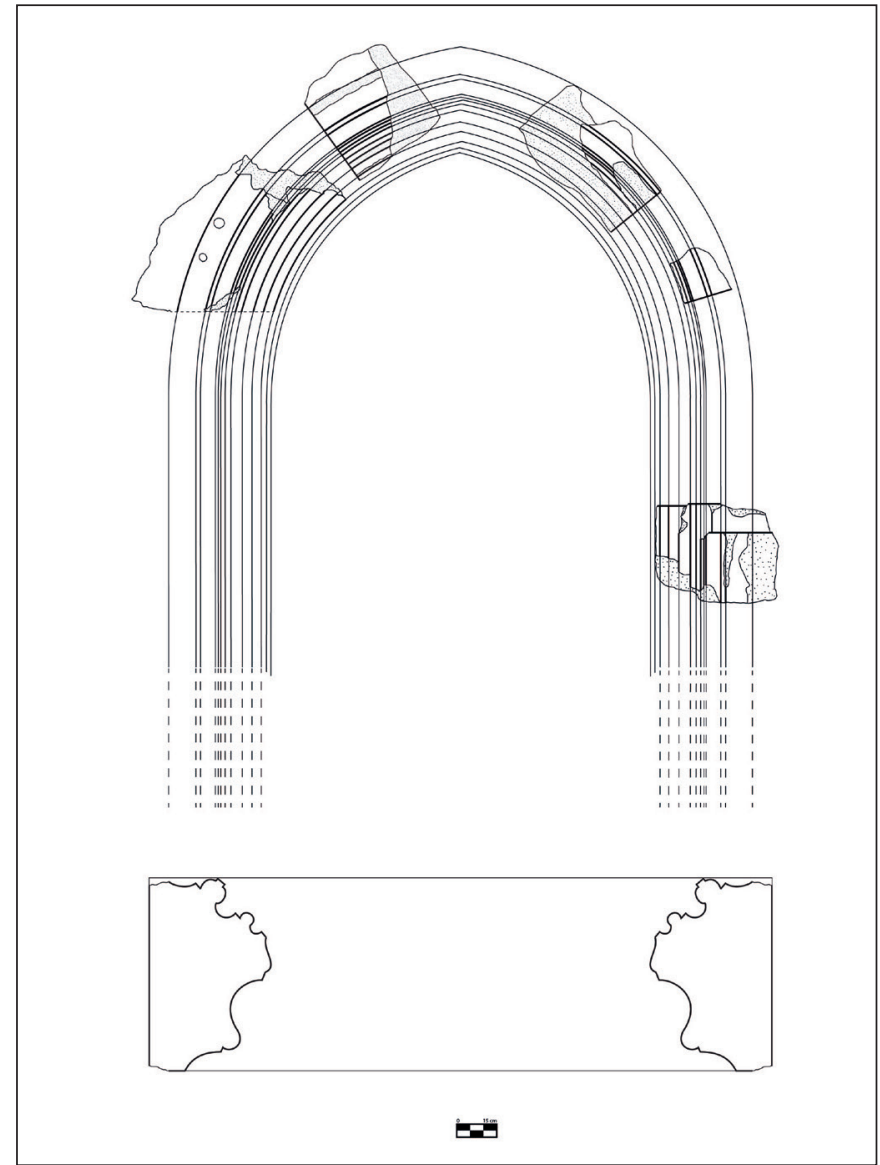

11. kép. A fökapu elméleti rekonstrukciója II.

nyíláskeret keltezése müvészettörténeti párhuzamok vizsgálata útján lehetséges. Két közeli analógia ismert számomra: az egyik az ozorai vár középkori (a mai nyugati) kapuja (Feld \& KopPÁNY 1987, 337, 343), valamint a kismartoni vár kapuja (HoLzschuH 1995). Mindkét nyíláskeret a 15. század első évtizedeire keltezhető, így a tatai is minden bizonnyal ekkor, vagyis a vár első építési periódus során készülhetett.

A legnagyobb, összesen 33 darab kőfaragványt tartalmazó csoport elemei mind egy ablakkeret részeit alkották egykor. A legtöbb példány pontos lelőhelye nem ismert, azonban néhányról tudjuk, hogy a mára teljesen elpusztult délnyugati saroktorony területéről (V betüvel jelölve; 1. kép), illetve annak környékéről (P betüvel jelölve; 1. kép) kerültek elő (Ásatási jelentés, 1970). Mindezeken túl pár faragványra a tatai Öreg-tó medrének északi részén bukkantak rá. A csoport elemei az azonos méretü és felépítésü profilkialakítások alapján voltak elkülöníthetők (12. kép). A faragott kövek között 13 darab keretkő, egy darab vízszintes és 19 darab függőleges ablakosztó található. A szárkövek lábazati lezárásai nem ismertek, azonban a függőleges ablakosztóké igen. A töredékek alapján tudjuk, hogy a pálcatag megvastagodott csavart lábazatban végződött, így minden bizonnyal a szárkövek lábazatain található pálcák végződése is hasonló lehetett. A csoport legnagyobb és egyben a legfontosabb tagján - egy szárkövön - két, középtengelyesen tükörszimmetrikus profil került kialakításra (1. számmal jelölve; 12. kép). Ennek a megfigyelésnek köszönhetően

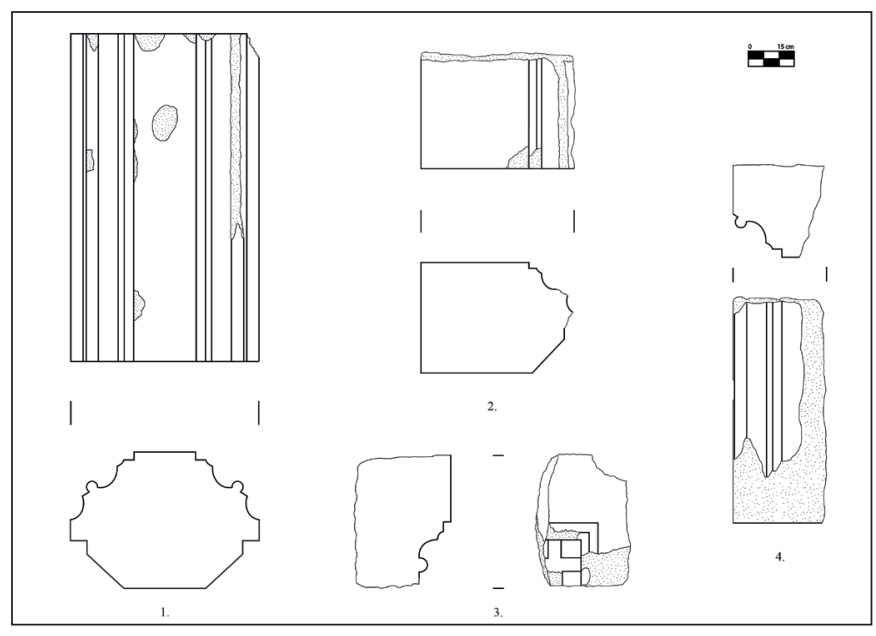

12. kép. Késő gótikus kettős ablak néhány töredéke 


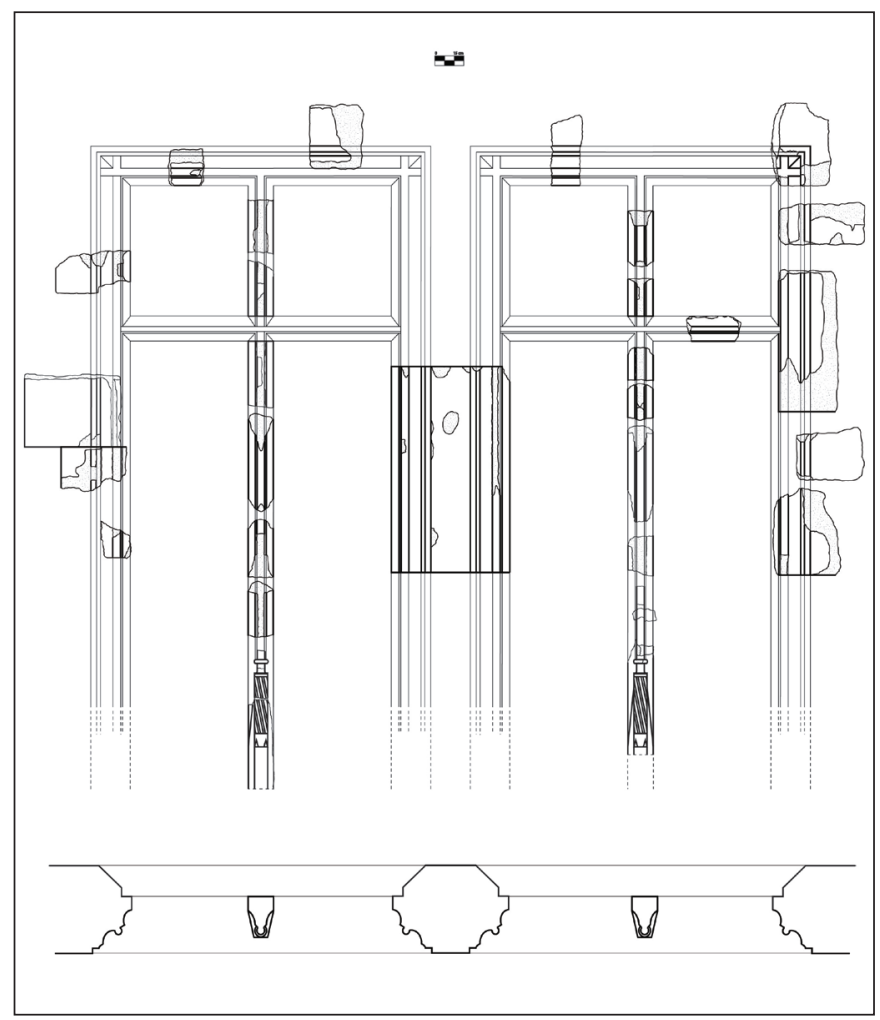

13. kép. Késő gótikus kettös ablak rekonstrukciója

egyértelmúvé vált, hogy ebben az esteben egy közös központi szárkővel rendelkező 2×2-es osztású ablak eleméröl van szó. A nagyszámú töredék ellenére az eredeti ablakkeret pontos méretei nem ismertek, ugyanis a feltárt elemek alapján erre a kérdésre nem lehet pontos választ adni. Egyedül az elöbb említett szimmetrikus szárkő nyújthat némi támpontot. Ezen ugyanis sem lábazati kialakítás, sem vízszintes ablakosztó csatlakozása nem figyelhető meg, ráadásul mindkét végén simára faragott illesztési sík található. Így ennek az elemnek mindenképpen a vízszintes ablakosztó és a lábazat között kellett elhelyezkednie. Mindezen bizonytalanságok ellenére vállalkoztam az ablakkeret elméleti rekonstrukciójának elkészítésére (13. kép). Két ehhez hasonló ablakkeret ismer ebböl a korszakból: az egyik a visegrádi királyi palotából (BuzÁs 1990, 249. kép), míg a másik a győri püspökvárból (SEDlmayr 1992, 52). A két ablak azonban a tataival ellentétben nem $2 \times 2$-es, hanem $2 \times 4$-es osztású, továbbá a profilkialakításaik is eltérőek. Azonban a két ablakban közös, hogy mindkettő egykor zárterkélyen helyezkedett el: a visegrádi építését Mátyás királyhoz, a győriét pedig az uralkodó egyik bizalmi emberéhez, Nagylucsei Orbán győri püspökhöz köti a kutatás (SEDLmaYr 1992, 52). Ezek alapján felvethető annak a lehetősége is, hogy a tatai vár második építési periódusában egy zárterkély kialakítására kerülhetett sor. A vár alaprajzán látható egy, az említett második építési periódusra keltezett négyszögletes alaprajzú építmény, melyet az északnyugati saroktorony elé építettek; ez véleményem szerint lehetne akár egy zárterkély alapozása is. (Bár ez csupán hipotézis, mindenképpen fontosnak tartom felvetni, annak ellenére is, hogy az ablak néhány töredéke nem innen, hanem a délnyugati saroktorony környékéröl került elö (V és P betükkel jelölve; 1. kép)). Ahogy fentebb említettem, a tatai ablak profilja nem egyezik a másik két zárterkély-ablak tagozataival, azonban több, a 15. század második feléből származó nyíláskerettel rokonítható. Ide sorolható három ablak a visegrádi királyi palotából (BuZÁs 1990, 239-241. kép), valamint Budáról (GEREVICH 1966, 285. és 405. kép) és Esztergomból (BuZÁs \& TolnAi 2004, 83-85; 5-8. kép) is ismertek analógiák. Továbbá a szeged-alsóvárosi ferences kolostorban található még egy ablakkeret, amelynek profil kialakítása szinte teljesen megegyezik a tatai kettős ablakéval (LuKÁCs 2000, 176; 63-64. képek). Az analógiák alapján a tatai 2×2-es nyíláskeret a 15. század utolsó negyedére, illetve a 16. század első évtizedére keltezhető.

Végezetül szeretnék még kitérni a gazdag mérmüdíszítéssel ellátott mellvédekre is, melyek a vár reprezentációjának legkiemelkedőbb példányai. A leletanyagban összesen öt darab gótikus mellvédtöredék különíthető el, melyek egykor három különböző szerkezet részét alkották. A régészeti feltárás során az egykori északi palotaszárny pincéjének feltöltésében ( $\mathrm{M}$ betüvel jelölve; 1. kép) egy gazdagon faragott gótikus vak kőrácsos mellvéd maradványai kerültek napvilágra (Ásatási jelentés, 1968). A töredékeket restaurálták és két nagyobb darabot sikerült összeállítani belölük (14. kép). Ezek alapján a mellvéd váltakozva két, egymás alatt vízszintesen tükör-

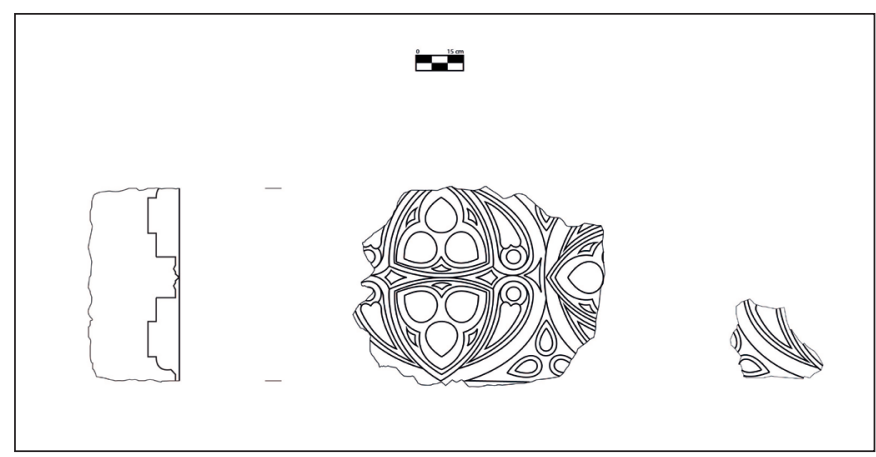

14. kép. A mellvéd I. töredékei 
Gillich Olivér • Egy uralkodói mellékrezidencia épitészeti elemei. A tatai vár 15. századi köfaragványai

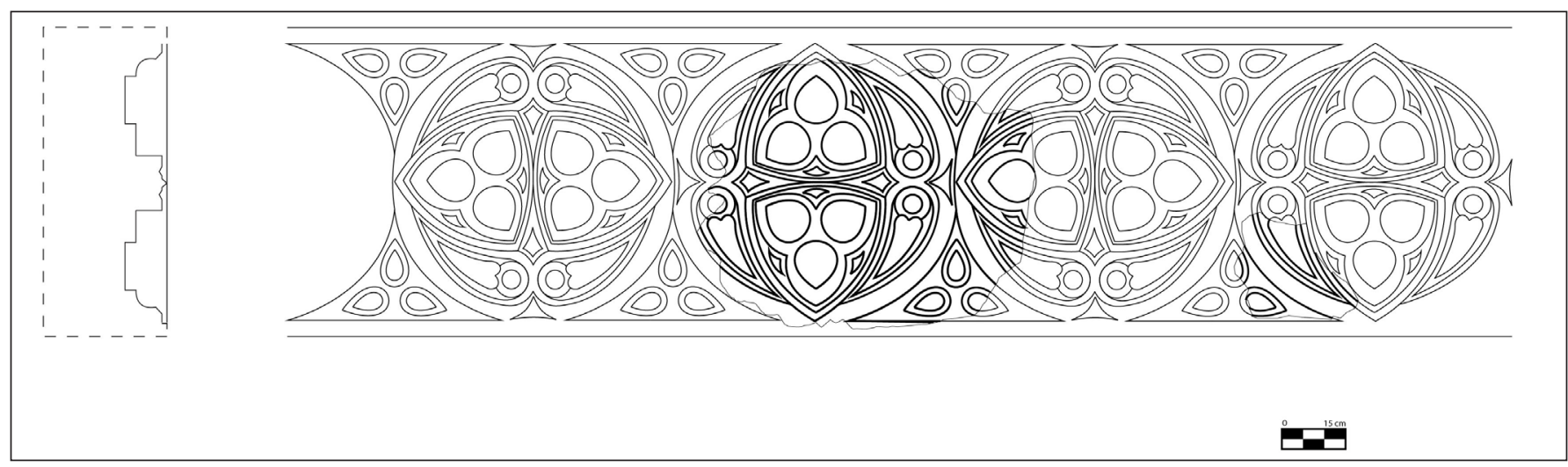

15. kép. A mellvéd I. elméleti rekonstrukciója

szimmetrikusan elhelyezkedő háromkaréjos elemből és azt kör alakú mezőbe foglalt négy halhólyagokból szerkesztett ornamentikából épül fel. A mellvéd analógiái megtalálhatóak a pozsonyi várban, illetve a bécsi Stephansdom nyugati karzatán (MAROSI 1983, 308-309). A töredékek alapján a rekonstrukciója megrajzolható volt (15. kép). Annak ellenére, hogy az északi palotaszárny területéről került elö, nem köthető egyértelműen ehhez az épületrészhez, ahogyan nem is zárható ki ide tartozása sem. További két mellvédhez tartozó darabok is megtalálhatóak a leletanyagban. Az egyiket (16. kép) a délnyugati torony területén ( $\mathrm{V}$ betüvel jelölve; 1 . kép) tárták fel (Ásatási jelentés, 1970) a másik (2-es számmal jelölve; 17. kép) pedig az Öreg-tóból került elő, a harmadik lelőhelye ismeretlen (1-es számmal jelölve; 17. kép). Rajzi rekonstrukcióra azonban csak az előbbi esetében volt lehetőségem (18. kép), melynek során két sorban elhelyezkedö, négykaréjos központú mezőket feltételezek. A faragvány közeli rokonságot mutat a csütörtökhelyi plébániatemplomhoz a 15. század második felében hozzáépített késő gótikus kápolna karzatának mellvédjével (Marosi 1987, 670). A másik két összetartozó faragvány középpontjában is négykaréjos elem található, azonban töredékességük miatt rajzi rekonstrukcióra nem vállalkoztam. A három mellvéd közül az egyik minden bizonnyal a várkápolna ( $\mathrm{F}$ betüvel jelölve; 1 . kép) felső terének karzatát díszíthette.

Összefoglalásként elmondható, hogy a tatai vár a 15. században élte a virágkorát, amit az írott források mellett a régészeti leletanyag is alátámaszt. Az 1965-1972 között folytatott ásatások által a felszínre hozott kőfaragványokkal és az ezek egy csoportja alapján készített rekonstrukciókkal is az építészetben megjelenő uralkodói reprezentáció egy szeletét kívántam bemutatni.

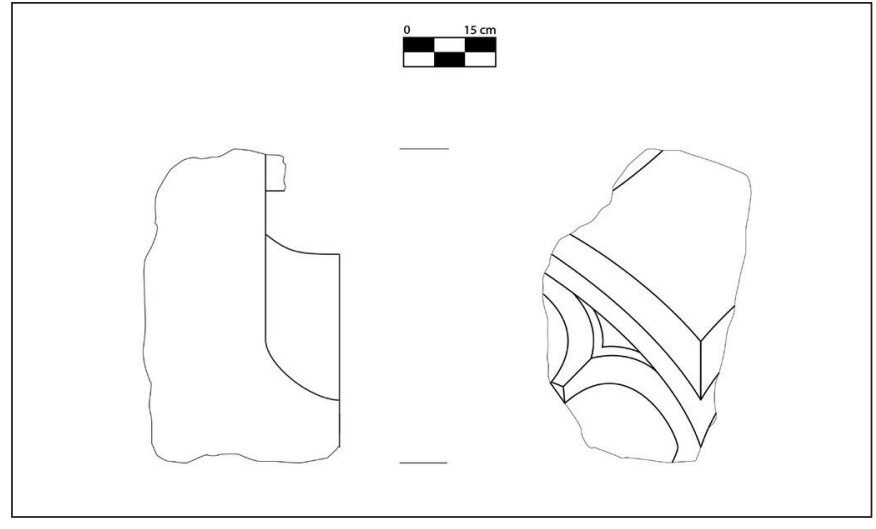

16. kép. A mellvéd II. töredéke

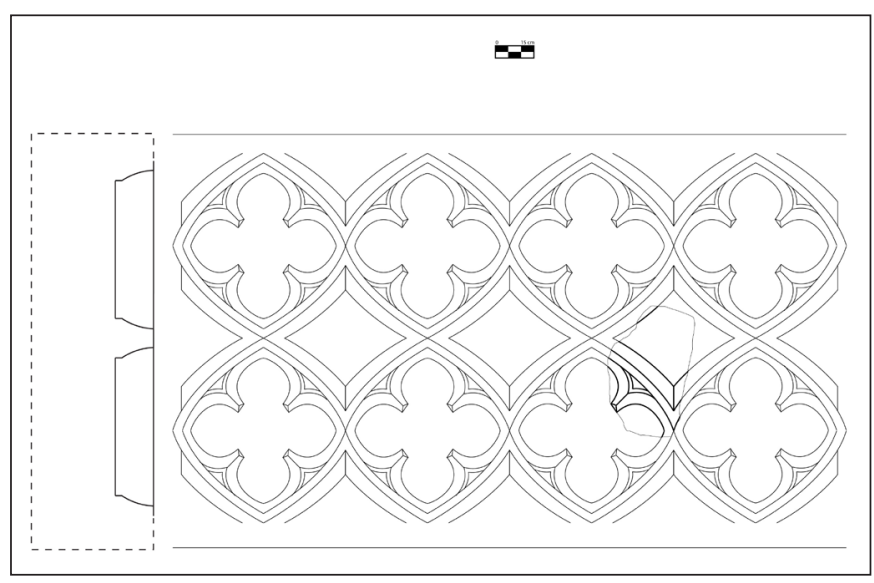

17. kép. A mellvéd II. elméleti rekonstrukciója

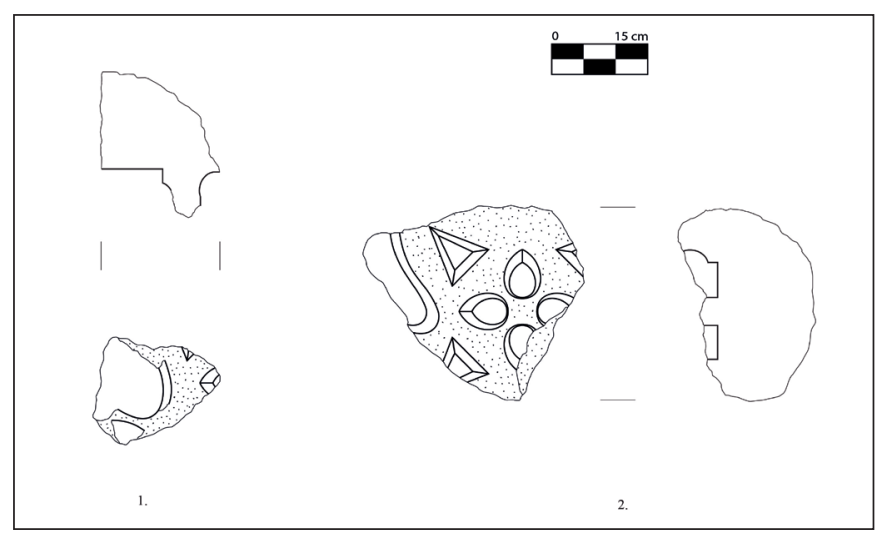

18. kép. A mellvéd III. töredékei 
Gillich Olivér • Egy uralkodói mellékrezidencia épitészeti elemei. A tatai vár 15. századi köfaragványai

BiBLIOGRÁFIA

Ásatási jelentések, 1965-1972. Kuny Domokos Megyei Múzeum Adattár.

B. Szatmári, S. (1974). Előzetes jelentés a tatai vár ásatásáról. Archaeologiai Értesítő 101, 45-53.

B. Szatmári, S. (1975). Tata. In Gerő László (szerk.), Várépitészetünk. Budapest: Müszaki Könyvkiadó.

Buzás, G. (1990). Visegrád, királyi palota I. A kápolna és az északkeleti palota. Lapidarium Hungaricum. Magyarország építészeti töredékeinek gyüjteménye 2. Pest megye I. Budapest: Országos Müemléki Felügyelőség.

Buzás, G. (2008). Ballusztrádos loggiák a magyar kora reneszánsz építészetben. Castrum - A Castrum Bene Egyesület folyóirata 8, 71-108.

Buzás, G. (2010). A tatai vár 1510-ben. In László János (szerk.), A diplomácia válaszútján. 500 éve volt Tatán országgyülés (pp. 93-113). Annales Tataienses 6. Tata: Tata Város Önkormányzata - KomáromEsztergom Megyei Önkormányzat Múzeumainak Igazgatósága.

Buzás, G. \& Tolnai, G. (2004). Az Esztergomi Vármúzeum Kötárának katalógusa. Az Esztergomi Vármúzeum Füzetei 2. Esztergom.

C. Tóth, N. (2010). Az út Tatáig. Országgyülések 1510-ben. In László János (szerk.), A diplomácia válaszútján. 500 éve volt Tatán országgyülés (pp. 9-28). Annales Tataienses 6. Tata: Tata Város Önkormányzata - Komárom-Esztergom Megyei Önkormányzat Múzeumainak Igazgatósága.

Engel, P. \& C. Tóth, N. (2005). Királyok és királynék itinerárumai (1382-1438). Segédletek a középkori magyar történelem tanulmányozásához 1. Budapest: Magyar Tudományos Akadémia Támogatott Kutatóhelyek Irodája.

Engel, P. (1977). Királyi hatalom és arisztokrácia viszonya a Zsigmond korban. Budapest: Akadémiai Kiadó.

Erdei, F. (1971). A tatai vár helyreállítása. Müemlékvédelem-Müemlékvédelmi és Épitészettörténeti Szemle $15(2), 80-82$.

Feld, I. \& Koppány, T. (1987). Az ozorai vár. In Beke László, Marosi Ernő \& Wehli Tünde (szerk.), Müvészet Zsigmond király korában 1387-1437. Tanulmányok 1. (pp. 332-346). Budapest: MTA Mủvészettörténeti Kutatócsoport.

Gerevich, L. (1966). A budai vár feltárása. Budapest: Akadémiai Kiadó.

Holzschuh, G. (1995). Zur Baugeschichte des Fürstlich Esterházyschen Schlosses in Eisenstadt. In J. M. Perschy (Hrsg.), Die Fürsten Esterházy. Ausstellungskatalog (pp. 144-155). Burgenländische Forschungen Sonderband 16. Eisenstadt.

Horváth, R. (2011). Itineraria regis Matthiae Corvini et reginae Beatricis de Aragonia (1458[1476]-1490). História Könyvtár, Kronológiák, Adattárak 12. Budapest: História - MTA Történettudományi Intézet. 
Gillich Olivér • Egy uralkodói mellékrezidencia épitészeti elemei. A tatai vár 15. századi köfaragványai

Lukács, Zs. (2000). A Szeged-alsóvárosi ferences kolostoregyüttes. In Kollár Tibor, Bardoly István \& Lővei Pál (szerk.), A középkori Dél-Alföld és Szer (pp. 143-192). Dél-Alföldi Évszázadok 13. Szeged: Csongrád Megyei Levéltár.

Marosi, E. (1983). Buda és Vajdahunyad, a 15. századi magyarországi építészettörténet tartópillérei. ÉpítésÉpitészettudomány 15, 293-310.

Marosi, E. (1987). Magyarországi müvészet 1300-1470 körül. Budapest: Akadémiai Kiadó.

Neumann, T. (2010). A tatai vár és urai a Jagelló-korban. In László János (szerk.), A diplomácia válaszútján. 500 éve volt Tatán országgyülés (pp. 66-92). Annales Tataienses 6. Tata: Tata Város Önkormányzata - Komárom-Esztergom Megyei Önkormányzat Múzeumainak Igazgatósága.

Schmidtmayer, R. (2012). Vértesi várak. A Rozgonyi család foúri rezidenciái a 15. században. In Péterfi Bence, Vadas András, Mikó Gábor \& Jakab Péter(szerk.), Micae Mediaevales II. Fiatal történészekdolgozatai a középkori Magyarországról és Európáról. (pp. 123-140). Budapest: ELTE BTK Történelemtudományok Doktori Iskola.

Schönerné, P. I. (1968). A tatai vár 1569-72-ből származó alaprajza. Komárom-Esztergom Megyei Múzeumok Közleményei 1, 263-272.

Sedlmayr, J. (1992). Késő gótikus zárt erkély a győri Püspökvárban. Müemlékvédelmi Szemle. Az Országos Müemléki Felügyelöség tájékoztatója 1, 48-53.

Tóth, S. (1998). A tatai vár ostromának szerepe a 15 éves háborúban. In: Fatuska János, Fülöp Éva Mária \& ifj. Gyüszi László (szerk.), Annales Tataienses I. Tata a tizenöt éves háborúban. (pp. 19-44). Tata: Mecénás Közalapítvány. 